\title{
ANALISIS SUMBER DAN PENGGUNAAN MODAL KERJA PADA KOPERASI SIMPAN PINJAM ARTHA GUNA BHAKTI TAHUN 2017 SINGARAJA
}

\author{
Kadek Nopi Yanti ${ }^{1}$, I Nyoman Sujana ${ }^{2}$, Anjuman Zukhri ${ }^{3}$ \\ Jurusan Pendidikan Ekonomi \\ Universitas Pendidikan Ganesha \\ Singaraja, Indonesia \\ e-mail:kadek181195@gmail.com, sujanatbn@yahoo.com \\ anjuman zukhri09@gmail.ac.id,
}

\begin{abstract}
Abstrak
Penelitian ini bertujuan untuk mengetahui, sumber modal kerja dan penggunaan modal kerja pada Koperasi Simpan Pinjam Artha Guna Bhakti Tahun 2017. Penelitian ini merupakan penelitian deskriptif kuantitatif. Subjek dalam penelitian ini adalah Koperasi Simpan Pinjam Artha Guna Bhakti, sedangkan objek dalam penelitian ini adalah sumber dan penggunaan modal kerja Koperasi Simpan Pinjam Artha Guna Bhakti periode 2015-2017. Sumber data yang digunakan adalah data sekunder. Data dikumpulkan dengan metode dokumentasi, dianalisis dengan analisis deskriptif. Hasil penelitian ini menunjukkan bahwa sumber modal kerja pada periode 2016-2017 berasal dari berkurangnya tabungan wajib pinjam, bertambahnya tabungan sukarela, bertambahnya simpanan berjangka, berkurangnya pinjaman luar, simpanan pokok, simpanan wajib, simpanan khusus dan cadangan. Penggunaan modal kerja pada periode 2016-2017 digunakan untuk piutang harian, piutang bulanan, penyertaan, biaya operasional dan akumulasi penyusutan.
\end{abstract}

Kata Kunci: penggunaan modal kerja, sumber modal

\begin{abstract}
The main purpose of this research was to identify, the source of working capital and the use working capital in Artha Guna Bhakti Saving and Loans Cooperative in 2017. The research is quantitative descriptive research. The subject in this research was Artha Guna Bhakti Savings and Loan Cooperatives, while the object was the source and use of working capital in Artha Guna Bhakti Savings and Loan Cooperative in the period 2015-2017. The data source that was used is secondary data. The method that was used to collect the data was documentation method and analyzed by descriptive analysis. The results of this study shows that the source of working capital in the period 2016-2017 comes from reduced compulsory savings and borrowing, increased voluntary savings, additional saving futures, reduced external loans, principal savings, mandatory savings, special deposits and reserves. The use of working capital in the period 2016-2017 is used for daily accounts receivable, monthly receivables, inclusion, operating expenses and accumulated depreciation.
\end{abstract}

Keywords: use of working capital, source of capital

\section{PENDAHULUAN}

Perkembangan ekonomi saat ini beraneka ragam dan perkembangannya begitu pesat. Persaingan yang begitu kuat didalam dunia usaha, membuat para pemilik usaha bersaing untuk mendapatkan keuntungan bagi usahanya. Banyak cara yang dilakukan pemilik usaha untuk mempertahankan usahanya, agar tetap berdiri ditengah persaingan yang begitu ketat saat ini. Tidak jarang beberapa sektor usaha yang ada mengalami banyak kendala dalam mempertahankan kelangsungan usahanya, oleh karena itu dibutuhkan badan usaha yang berperan untuk mewujudkan masyarakat yang maju, 
adil dan makmur yang mengutamakan kesejahteraan bersama, sehingga tercipta suatu tatanan hidup yang selaras dengan UUD 1945 khususnya pasal 33 ayat 1 yang berbunyi "perekonomian disusun sebagai suatu usaha bersama berdasarkan atas asas kekeluargaan". Bentuk usaha yang sesuai dengan asas di atas adalah koperasi.

Koperasi adalah badan usaha yang beranggotakan orang seorang atau badan hukum dengan melaksanakan kegiatan berdasarkan prinsip koperasi, sekaligus sebagai ekonomi rakyat yang berdasarkan asas kekeluargaan. Menurut Kasmir (2014:254), koperasi merupakan salah satu bentuk badan hukum yang sudah lama dikenal di Indonesia. Jadi koperasi merupakan bentuk dari sekelompok orang yang memiliki tujuan bersama. Kelompok orang inilah yang akan menjadi anggota koperasi yang didirikannya. Menurut Undang-Undang Republik Indonesia Tahun 2012 tentang perkoperasian di dalamnya disebutkan bahwa jenis-jenis koperasi didasarkan pada kesamaan kegiatan usaha dan atau kepentingan ekonomi anggota, terdiri atas koperasi konsumen, produsen, jasa, dan simpan pinjam. Menurut Sukamdiyo (2001:2), "koperasi merupakan badan usaha yang beranggotakan orangseorangan atau badan hukum koperasi dengan melandaskan kegiatannya berdasarkan prinsip koperasi sekaligus sebagai gerakan ekonomi rakyat yang berdasarkan atas asas kekeluargaan". Menurut Kasmir (2014:254), "koperasi adalah salah satu bentuk badan hukum yang sudah lama dikenal di Indonesia, jadi koperasi merupakan bentukan dari sekelompok orang yang memiliki tujuan bersama. Kelompok orang inilah yang akan menjadi anggota koperasi yang didirikannya". Dalam penelitian ini peneliti melakukan penelitian di koperasi simpan pinjam karena koperasi simpan pinjam kegiatan utamanya adalah menyediakan jasa penyimpanan dan peminjaman dana kepada anggota koperasi. Menurut Subandi (2010:35), "koperasi kredit atau simpan pinjam adalah koperasi yang bergerak dalam pemupukan simpanan dari para anggotanya untuk dipinjamkan kembali kepada anggotanya yang membutuhkan bantuan modal untuk usahanya". Selain itu, koperasi simpan pinjam juga bertujuan mendidik anggotanya dari jeratan rentenir. Menurut Rudianto (2010:51), "koperasi simpan pinjam adalah koperasi yang bergerak dalam bidang pemupukan simpanan dana dari para anggotanya, untuk kemudian dipinjamkan kembali kepada para anggota yang memerlukan bantuan dana".

Kegiatan utama koperasi simpan pinjam adalah menyediakan jasa penyimpanan dan peminjaman dana kepada anggota koperasi. Walaupun pemupukan modal dilakukan koperasi dari para anggotanya, sering kali jumlah uang yang ingin dipinjamkan oleh anggota lebih besar dari modal yang dimiliki koperasi, seperti bank atau koperasi kredit. Jadi pada dasarnya fungsi koperasi simpan pinjam adalah sebagai jembatan antara koperasi yang memerlukan uang pinjaman dengan anggota koperasi yang menyimpan uangnya di koperasi atau kreditor. Koperasi adalah suatu perkumpulan yang didirikan oleh yang memiliki kemampuan ekonomi terbatas, yang bertujuan untuk memperjuangkan peningkatan kesejahteraan ekonomi anggotanya, sedangkan koperasi simpan pinjam adalah koperasi yang kegiatannya menghimpun dan menyalurkannya kembali melalui kegiatan usaha simpan pinjam dari dan untuk anggota koperasi yang bersangkutan, calon anggota koperasi yang bersangkutan, koperasi lain dan atau anggotanya (Subandi, 2010:35).

Seperti halnya bentuk badan usaha yang lain untuk menjalankan kegiatan usahanya koperasi simpan pinjam memerlukan sejumlah modal. Adapun sumber-sumber dana yang diperlukan koperasi simpan berdasarkan pedoman tata cara pendirian koperasi terdiri atas modal sendiri dan modal pinjaman. Modal sendiri meliputi simpanan pokok adalah sejumlah uang yang wajib dibayarkan oleh anggota kepada koperasi pada saat masuk menjadi anggota. Simpanan pokok tidak dapat diambil kembali selama yang bersangkutan masih menjadi anggota koperasi. Simpanan pokok jumlahnya sama untuk setiap anggota, simpanan wajib adalah jumlah simpanan tertentu yang harus dibayarkan 
oleh anggota kepada koperasi dalam waktu dan kesempatan tertentu, dana cadangan adalah sejumlah uang yang diperoleh dari penyisihan sisa hasil usaha, yang dimaksudkan untuk pemupukan modal sendiri, pembagian kepada anggota yang keluar dari keanggotaan koperasi, dan untuk menutup kerugian koperasi bila diperlukan, dan hibah adalah sejumlah uang atau barang yang dapat dinilai dengan uang yang diterima dari pihak lain yang bersifat hibah atau pemberian dan tidak mengikat.

Adapun modal pinjaman koperasi simpan pinjam berasal dari pihak-pihak yaitu anggota dan calon anggota, koperasi lainnya dan atau anggota didasari dengan perjanjian kerja sama antar koperasi, bank dan lembaga keuangan lainnya yang dilakukan berdasrkan ketentuan peraturan perundang-undangan yang berlaku, penerbitan obligasi dan surat utang lainnya yang dilakukan berdarkan ketentuan perundang-undangan yang berlaku, dan sumber lain yang sah seperti modal penyertaan dan pinjaman lainnya.

Tujuan utama koperasi dalam Undang-Undang RI Nomor 25 Tahun 1992 adalah memajukan kesejahteraan anggota pada khususnya dan masyarakat pada umumnya serta ikut membangun tatanan perekonomian nasional dalam rangka mewujudkan masyarakat yang maju, adil, dan makmur berlandaskan Pancasila dan Undang-Undang Dasar 1945. Koperasi harus dikelola dengan sebaik baiknya. Salah satunya dengan melakukan analisis laporan keuangan koperasi, yang diwujudkan dalam laporan keuangan.

$$
\text { Laporan keuangan koperasii }
$$

merupakan salah satu sumber informasi yang penting, dimana akan dapat menentukan langkah-langkah yang harus ditempuh. Tujuan umum laporan keuangan koperasi yaitu memberikan informasi keuangan yang dapat dipercaya mengenai sumber-sumber ekonomi dan kewajiban maupun modal suatu koperasi, memberikan informasi yang dapat dipercaya mengenai perubahan atas sumber-sumber ekonomi dan kewajiban maupun modal karena adanya aktivitas usaha dalam rangka modal karena adanya aktivitas usaha dalam rangka memperoleh sisa hasil usaha(SHU) suatu koperasi, membantu para pemakai informasi keuangan dalam rangka mengestimasi potensi koperasi dalam menghasilkan SHU dimasa akan datang, dan mengungkapkan informasi lainnya yang berhubungan dengan laporan keuangan yang relevan seperti informasi tentang kebijakan yang dianut oleh koperasi.

Banyak diantara usaha koperasi yang tidak mampu meneruskan usahanya yang disebabkan oleh kurang baiknya pengelolaan manajemen dalam melaksanakan kegiatan. Salah satu cara untuk mengatasi hal tersebut, maka diperlukan analisis laporan keuangan secara periodic. Analisis sumber dan penggunaan modal kerja adalah melakukan penganalisisan laporan keuangan dengan tujuan memperoleh informasi perubahan modal kerja koperasi baik sumber modal kerja dan penggunaan modal kerja pada suatu periode.

Menurut Undang-Undang Republik Indonesia No. 25, pasal 41 tentang modal koperasi, modal koperasi terdiri dari modal sendiri dan modal pinjaman. Modal sendiri meliputi simpanan pokok, simpanan wajib, dana cadangan, dan hibah. Modal pinjaman koperasi berasal dari anggota, koperasi lainnya dan atau anggotanya, bank dan lembaga keuangan lainnya, penerbitan obligasi dan surat hutang lainnya dan sumber lain yang sah. Menurut Riyanto (2001) modal kerja menurut jenisnya dapat dibedakan menjadi dua golongan yaitu modal kerja permanen dan modal kerja variabel.

Menurut Jumingan (2008), Modal kerja adalah kelebihan aktiva lancar terhadap hutang jangka pendek. Kelebihan ini disebut dengan modal kerja bersih (net working capital). Kelebihan ini merupakan jumlah aktiva lancar yang berasal dari utang jangka panjang dan modal sendiri. Definisi ini bersifat kualitatif karena menunjukkan kemungkinan tersedianya aktiva lancar yang lebih besar daripada utang jangka pendek dan menunjukkan tingkat keamanan bagi kreditur jangka pendek serta menjamin kelangsungan diusaha mendatang, sedangkan menurut Amidipradja (2005) menjelaskan bahwa modal kerja koperasi adalah kelebihan 
jumlah harta terhadap jumlah utang dari koperasi, atau dengan kata lain selisih positif antara harta dan utang. Modal kerja adalah factor yang sangat penting bagi perkembangan dan kemajuan koperasi sekaligus berfungsi sebagai penjaga kepercayaan masyarakat.

Menurut Sujarweni (2017:186), "modal kerja merupakan investasi perusahaan dalam bentuk uang tunai, surat berharga, piutang dan persediaan, dikurangi dengan kewajiban lancar yang digunakan untuk membiayai aktiva lancar, dan modal kerja dapat dikategorikan menjadi dua yaitu modal kerja kotor dan modal kerja bersih. Modal kerja kotor adalah jumlah aktiva lancar dan modal kerja adalah jumlah harta lancar dikurangi jumlah utang lancar. Menurut Sutrisno (2007:39), "modal kerja adalah dana yang diperlukan oleh perusahaan untuk memenuhi kebutuhan operasional perusahaan seharihari. Seperti pembelian bahan baku, pembayaran upah buruh, membayar hutang dan pembayaran lainnya".

Menurut Riyanto (2001), modal kerja menurut jenisnya dapat dibedakan menjadi dua golongan yaitu modal kerja permanen dan modal kerja variabel. Menurut Sartono (2010) modal kerja diperlukan perusahaan untuk membiayai kegiatan operasional perusahaan, sumber modal kerja menurut Munawir (2004) adalah adanya penurunan dalam non current assets karena penjualan maupun proses depresiasi, kenaikan dalam non current liabilities atau hutang jangka panjang, dan adanya kenaikan dalam sector modal dari setoran pemilik maupun dari hasil operasi. Modal kerja sebaiknya tersedia dalam jumlah yang cukup agar memungkinkan koperasi untuk beroperasi secara ekonomis dan tidak mengalami kesulitan keuangan, misalnya dapat menutup kerugian dan mengatasi keadaan krisis atau darurat tanpa membahayakan keadaan keuangan koperasi. Manfaat tersedianya modal kerja yang cukup yaitu melindungi koperasi dari akibat buruk berupa nilai aktiva lancar, memungkinkan koperasi untuk melunasi kewajibankewajiban jangka pendek tepat pada waktunya, memungkinkan koperasi untuk dapat membeli barang dengan tunai sehingga dapat keuntungan berupa potongan harga, memungkinkan koperasi memiliki persediaan dalam jumlah yang cukup guna melayani permintaan konsumennya, memungkinkan koperasi dapat memberikan syarat kredit yang menguntungkan kepada anggotanya, dan memungkinkan koperasi dapat beroperasi dengan lebih efisien karena tidak ada kesulitan dalam memperoleh bahan baku, jasa, dan suplai yang dibutuhkan.

Setelah memperoleh modal kerja yang diinginkan, kemudian koperasi menggunakan modal kerja tersebut untuk mencapai tujuannya. Hubungan antara sumber dan penggunaan modal kerja sangat erat, artinya penggunaan modal kerja dipilih dari sumber modal tertentu atau sebaliknya.

Sumber modal kerja dalam koperasi sangatlah penting. Sumber modal kerja adalah untuk mengetahui bagaimana memenuhu kebutuhan dana tersebut (Sudarsono \& Edilius, 2004:193). Menurut Munawir (2004), sumber modal kerja adalah penurunan dalam non current assets karena penjualan maupun proses depresiasi, kenaikan dalam non current liabilities atau hutang jangka panjang, dan adanya kenaikan dalam sector modal dari setoran pemilik maupun dari hasil operasi, jadi definisi yang berkaitan sumber modal kerja adalah alat untuk mengetahui bagaimana sebuah perusahaan memenuhi kebutuhan dananya. Menurut Sudarsono dan Edilius (2004:195) yang merupakan sumber dari modal kerja yaitu berkurangnya aktiva tetap, bertambahnya hutang jangka panjang, bertambahnya modal, da nada keuntungan dari operasi perusahaan.

Sumber modal kerja adalah dana yang diperoleh dari dalam perusahaan maupun dari luar perusahaan. Penggunaan modal kerja akan mengakibatkan perubahan bentuk maupun penurunan jumlah aktiva lancar yang dimiliki oleh perusahaan, tetapi penggunaan aktiva lancar tidak selalu diikuti dengan berubahnya atau turunnya jumlah modal kerja yang dimiliki oleh perusahaan. Sumber modal kerja diantaranya yaitu hasil operasi perusahaan, keuntungan penjualan surat-surat berharga, penjualan aktiva tidak lancar, penjualan saham atau obligasi, dan 
penerimaan pinjaman jangka panjang (Sujarweni, 2017:186)

Penggunaan modal kerja akan dapat mempengaruhi jumlah modal kerja itu sendiri. Menurut Kasmir (2014), seorang manajer dituntut untuk menggunakan modal kerja secara tepat, sesuai dengan saran yang ingin dicapai perusahaan. Penggunaan dana untuk untuk modal kerja dapat diperoleh dari kenaikan aktiva dan menurunnya pasiva. Penggunaan modal kerja menurut Munawir (2004) adalah adanya kenaikan sektor non current asset, penurunan dalam sector non current liabilities atau hutang jangka panjang, dan adanya kerugian dalam sector modal dan operasi perusahaan, sedangkan penggunaan modal kerja menurut Kasmir (2014) penggunaan modal kerja bisa dilakukan untuk pengeluaran gaji, upah, dan biaya operasional, pengeluaran untuk membeli bahan baku atau bahan dagangan, menutupi kerugian akibat penjualan surat berharga, pembentukan dana, pembelian aktiva tetap, pembayaran hutang jangka panjang, dan penggunaan lainnya.

Penggunaan modal kerja akan menyebabkan perubahan bentuk maupun penurunan jumlah aktiva lancar yang dimiliki dengan berubahnya atau turunnya jumlah modal kerja yang dimiliki oleh perusahaan. Penggunaan aktiva lancar yang mengakibatkan turunnya modal kerja yaitu pembayaran biaya atau ongkosongkos operasi perusahaan, kerugiankerugian yang diderita oleh perusahaan, adanya pembentukan dana atau pemisahan aktiva lancar untuk tujuan-tujuan tertentu, adanya penambahan atau pembelian aktiva tetap, investasi jangka panjang, atau aktiva tidal lancar lainnya, pembayaran hutanghutang jangka panjang, dan pengambilan uang atau barang dagangan (Munawir, 1993:125).

Penggunaan modal kerja menurut Sudarsono \& Edilius (2004:195), yang merupakan penggunaan modal kerja yaitu bertambahnya aktiva tetap, berkurangnya hutang jangka panjang, berkurangnya modal, pembayaran kas deviden, dan adanya kerugian dalam operasi perusahaan. Tujuan penggunaan modal kerja menurut Munawir (2004:113), tujuan sumber dan penggunaan modal kerja merupakan alat keuangan yang sangat penting bagi financial manager ataupun para calon kreditur atau bagi bank dalam permintaan kredit yang diajukan kepadanya. Dengan penggunaan modal kerja akan dapat diketahui bagaimana perubahan mengelola atau menggunakan modal kerja yang dimiliki". Menurut Sudarsono \& Edilius (2004:193), "tujuan sumber dan penggunaan modal kerja adalah untuk mengetahui bagaimana modal kerja digunakan dan bagaimana memenuhi kebutuhan modal kerja tersebut". Jadi tujuan utama penggunaan modal kerja yaitu untuk mengetahui efisiensi perusahaan dalam penggunaan modal kerja, untuk memberikan pemahaman terhadap operasi keuangan perusahaan, dan untuk memperkirakan apakah perusahaan telah berkembang dengan cepat dan apakah perusahaan mulai kehabisan sumbersumber pembelanjaan.

Koperasi simpan Pinjam Artha Guna Bhakti merupakan salah satu koperasi yang bergerak dalam bidang usaha simpan pinjam. Salah satu sumber modal terbesar yang didapat oleh KSP Artha Guna Bhakti bersumber dari bidang simpan pinjam dengan jenis kredit harian dan bulanan saja, dengan semakin banyaknya anggota yang bergabung maka simpanan pokok dan simpanan wajib pun meningkat, hal ini akan mempengaruhi besarnya sumber modal bagi KSP Artha Guna Bhakti.

Selama kurun waktu dari tahunketahun modal kerja KSP Artha Guna Bhakti mengalami penurunan maupun peningkatan. Tahun 2015-2016 sumber modal kerja KSP Artha Guna Bhakti mengalami peningkatan pada tahun 2016 jika dibandingkan dengan tahun 2015. Tahun 2015 jumlah modal kerja koperasi sebesar Rp 315.150.213, sedangkan tahun 2016 jumlah modal kerja koperasi sebesar Rp 371.703.487, sehingga dapat dikatakan modal kerja koperasi pada tahun 2016 mengalami peningkatan modal kerja sebesar $\mathrm{Rp}$ 56.553.274. sehingga dari peningkatan tersebut banyak biaya-biaya yang tidak seimbang dengan kenaikan aktiva lancarnya.

Berdasarkan uraian di atas, maka penulis tertarik untuk melakukan penelitian 
dengan judul analisis sumber dan penggunaan modal kerja pada Koperasi Simpan Pinjam Artha Guna Bhakti tahun 2017. Tujuan yang ingin dicapai dalam penelitian ini adalah untuk mengetahui sumber dan penggunaan modal kerja pada Koperasi Simpan Pinjam Artha Guna Bhakti (KSP AGB) tahun 2017.

\section{METODE}

Rancangan penelitian yang digunakan adalah penelitian deskriptif pada KSP Artha Guna Bhakti yaitu untuk mengetahui apa saja sumber modal kerja dan bagaimana penggunaannya. Data yang dicari adalah laporan keuangan berupa neraca tahun 2015, 2016, dan 2017. Data tersebut kemudian dianalisis dengan menggunakan analisis perbandingan.

Dengan membandingkan pos-pos pada neraca pada tahun 2015-2017 yang berhubungan dengan sumber dan penggunaan modal kerja bertujuan untuk mendapatkan informasi perkembangan keadaan keuangan koperasi. Hasil analisis laporan sumber dan penggunaan modal kerja diharapkan dapat membantu pengelola koperasi mengetahui apa saja sumber modal koperasi dan bagaimana penggunaan modal kerja selama periode tersebut, sehingga dari hasil penelitian tersebut dapat digunakan pengelola koperasi untuk mengambil keputusan tentang permodalan.

Lokasi penelitian adalah di Koperasi Simpan Pinjam Artha Guna Bhakti yang beralamat di Jalan Gunung Agung III/2 Paket Agung-Singaraja, Kecamatan Buleleng, Kabupaten Buleleng, Provinsi Bali. Subjek dalam penelitian ini adalah KSP Artha Guna Bhakti, laporan yang digunakan merupakan laporan keuangan berupa neraca periode 2015-2017. Objek kajian penelitian ini adalah sumber dan penggunaan modal kerja pada KSP Artha Guna Bhakti. Berdasarkan jenisnya, data yang digunakan dalam penelitian ini adalah data kuantitatif. Data kuantitatif yang digunakan berupa Neraca KSP Artha Guna Bhakti. Berdasarkan sumbernya, data yang digunakan dalam penelitian ini adalah data sekunder. Data sekunder yang digunakan meliputi laporan keuangan berupa Neraca KSP Artha Guna Bhakti.
Metode pengumpulan data yang digunakan dalam penelitian ini adalah dokumentasi. Dokumen yang digunakan berupa laporan keuangan koperasi yaitu Neraca. Analisis data yang digunakan dalam penelitian ini adalah deskriptif kuantitatif. Penelitian ini disajikan dalam bentuk deskriptif yang membahas tentang dari mana saja sumber modal koperasi dan apa saja penggunaan modal kerja koperasi.

Tahap-tahap analisis data dapat dilakukan setelah memperoleh data dengan metode dokumentasi berupa neraca koperasi pada tahun 2015-2017, kemudian data-data tersebut diolah dan dianalisis untuk mencapai tujuan akhir penelitian. Dalam hal ini peneliti melakukan analisis perbandingan yaitu membandingkan pospos yang ada pada neraca yang berhubungan dengan sumber dan penggunaan modal kerja. Neraca yang diperbandingkan untuk dua atau beberapa tahun misalnya laporan keuangan tahun 2015, dibandingkan dengan laporan keuangan tahun 2016. Hasil dari perbandingan neraca dua periode untuk mengetahui perubahan-perubahan kenaikan atau penurunan pos-pos laporan keuangan atau data lainnya dalam dua periode yang dibandingkan, dan menentukan bagaimana setiap pos laporan keuangan berubah, dan mengetahui apakah perubahan tersebut menguntungkan atau tidak. Menyusun laporan perubahan modal kerja. Laporan tentang perubahan modal kerja memerlukan adanya analisa tentang kenaikan atau penurunan dalam pos-pos yang tercantum dalam neraca yang diperbandingkan antara dua periode tertentu, hal ini menunjukkan perubahanperubahan yang terjadi dalam pos-pos elemen modal kerja tersebut. Dalam menganalisis perubahan yang terjadi dalam sector non current ( aktiva tetap, hutang jangka panjang. Dan modal). Oleh karena itu laporan perubahan modal kerja harus menunjukkan kedua hal tersebut dan dapat disajikan dalam dua bagian, dan menyusun laporan sumber dan penggunaan modal kerja. Laporan sumber dan penggunaan modal kerja berisi sumber-sumber modal kerja merupakan perubahan unsur-unsur dari laporan neraca dan laporan sisa hasil 
usaha (SHU) yang menyebabkan modal kerja koperasi bertambah dan berisi penggunaan modal kerja yang merupakan unsur-unsur dari laporan neraca dan laporan sisa hasil usaha (SHU) yang menyebabkan modal kerja koperasi berkurang.

\section{HASIL DAN PEMBAHASAN Hasil}

Berdasarkan hasil analisis sumber modal kerja yang telah dilakukan pada Koperasi Simpan Pinjam Artha Guna Bhakti pada periode tahun 2015-2017, total sumber modal kerja Koperasi Simpan Pinjam Artha Guna Bhakti pada periode tahun 2015-2016 adalah sebesar Rp $844,419,232$, dapat diuraikan unsur-unsur non current yang memperbesar modal kerja (sumber modal kerja). Sumber-sumber modal kerja KSP Artha Guna Bhakti periode 2015-2016 berasal dari berkurangnya tabungan wajib pinjam periode 2015-2016 yaitu sebesar $R p$ 12,316,500, karena pada tahun 2015 tabungan wajib pinjam KSP Artha Guna Bhakti adalah Rp $66,168,800$, sedangkan tabungan wajib pinjam KSP Artha Guna Bhakti pada tahun 2016 sebesar $\operatorname{Rp} 53,852,300$, bertambahnya tabungan sukarela periode 2015-2016 yaitu sebesar $R p$ 134,583,116, karena pada tahun 2015 tabungan sukarela KSP Artha Guna Bhakti yaitu sebesar Rp 935,782,350, sedangkan tabungan sukarela KSP Artha Guna Bhakti pada tahun 2016 sebesar Rp $1,070,365,466$, bertambahnya simpanan berjangka periode 2015-2016 yaitu sebesar Rp 226,000,000, karena pada tahun 2015 simpanan berjangka KSP Artha Guna Bhakti adalah Rp 2,064,800,000, sedangkan tahun 2016 simpanan berjangka KSP Artha Guna Bhakti adalah Rp $2,290,800,000$, bertambahnya pinjaman luar periode 2015-2016 yaitu sebesar $R p$ $17,500,000$, karena pada tahun 2015 pinjaman luar KSP Artha Guna Bhakti adalah $\mathrm{Rp} 38,750,000$, sedangkan pada tahun 2016 pinjaman luar KSP Artha Guna Bhakti adalah Rp 56,250,000, bertambahnya simpanan pokok periode 2015-2016 yaitu sebesar $\mathrm{Rp} 500,000$, karena pada tahun 2015 simpanan pokok KSP Artha Guna Bhakti adalah Rp 24,000,000, sedangkan tahun 2016 simpanan pokok KSP Artha Guna Bhakti adalah $\mathrm{Rp}$ 24,500,000, bertambahnya simpanan wajib periode 2015-2016 yaitu sebesar $\operatorname{Rp} 30,310,000$, bertambahnya simpanan khusus periode 2015-2016 yaitu sebesar Rp 1,000,000, dan bertambahnya ekuitas (cadangan) yaitu sebesar $R p$ 24,743,274, karena pada tahun 2015 cadangan KSP Artha Guna Bhakti adalah Rp 65,830,213, sedangkan tahun 2016 cadangan KSP Artha Guna Bhakti adalah Rp 90,573,487.

Hasil analisis sumber modal kerja yang telah dilakukan pada KSP Artha Guna Bhakti pada periode 2016-2017, total sumber modal kerja pada periode 20162017 adalah $\operatorname{Rp} 1,563,344,128$, dapat diuraikan unsur-unsur non current yang memperbesar modal kerja (sumber modal kerja). Sumber-sumber modal kerja pada KSP Artha Guna Bhakti periode 2016-2017 berasal dari berkurangnya tabungan wajib pinjam KSP Artha Guna Bhakti yaitu sebesar Rp 2,705,500, karena pada tahun 2016 tabungan wajib pinjam KSP Artha Guna Bhakti adalah Rp 53,852,300, sedangkan pada tahun 2017 tabungan wajib pinjam KSPArtha Guna Bhakti adalah Rp 51,146,800, bertambahnya tabungan sukarela pada KSP Artha Guna Bhakti yaitu sebesar $R p$ 279,048,513, karena pada tahun 2016 tabungan sukarela KSP Artha Guna Bhakti adalah Rp 1,070,365,466, sedangkan tahun 2017 tabungan sukarela adalah $\operatorname{Rp} 1,349,413,979$, bertambahnya simpanan berjangka KSP Artha Guna Bhakti yaitu sebesar Rp 1,156,200,000, karena pada tahun 2016 simpanan berjangka KSP Artha Guna Bhakti adalah Rp 2,290,800,000, sedangkan pada tahun 2017 simpanan berjangka KSP Artha Guna Bhakti adalah Rp 3,447,000,000, berkurangnya pinjaman luar KSP Artha Guna Bhakti yaitu sebesar Rp $37,500,000$, karena pada tahun 2016 pinjaman luar KSP Artha Guna Bhakti adalah Rp 56,250,000, sedangkan tahun 2017 pinjaman luar KSP Artha Guna Bhakti adalah Rp 18,750,000, simpanan pokok KSP Artha Guna Bhakti yaitu sebesar $R p$ 9,575,000, simpanan wajib KSP Artha Guna Bhakti yaitu sebesar Rp 49,340,000, simpanan khusus KSP Artha Guna Bhakti yaitu sebesar Rp 
3,000,000, dan cadangan KSP Artha Guna Bhakti yaitu sebesar Rp 25,975,115.

$$
\text { Berdasarkan hasil analisis }
$$

penggunaan modal kerja yang telah dilakukan pada KSP Artha Guna Bhakti pada periode tahun 2015-2016, total penggunaan modal kerja pada tahun 20152016 adalah $\mathrm{Rp} 632,307,640$, dapat diuraikan unsur-unsur non current yang memperkecil modal kerja (penggunaan modal kerja). Penggunaan modal kerja pada KSP Artha Guna Bhakti periode tahun 2015-2016 yaitu berkurangnya piutang harian KSP Artha Guna Bhakti yaitu sebesar $R p$ 8,033,500, karena pada tahun 2015 piutang harian KSP Artha Guna Bhakti adalah Rp 407,371,500, sedangkan tahun 2016 piutang harian KSP Artha Guna Bhakti adalah $\mathrm{Rp} 399,338,000$, bertambahnya piutang bulanan KSP Artha Guna Bhakti yaitu sebesar Rp 524,123,200, karena pada tahun 2015 pinjaman bulanan KSP Artha Guna Bhakti adalah Rp 2,151,353,700, sedangkan pinjaman luar tahun 2016 KSP Artha Guna Bhakti adalah Rp 2,675,476,900, penyertaan KSP Artha Guna Bhakti yaitu sebesar Rp 3,700,000, karena pada tahun 2015 KSP Artha Guna Bhakti adalah Rp $30,640,000$, sedangkan tahun 2016 penyertaan KSP Artha Guna Bhakti adalah Rp 34,340,000, bertambahnya biaya operasional KSP Artha Guna Bhakti yaitu sebesar Rp 92,950,940, karena pada tahun 2015 biaya operasional KSP Artha Guna Bhakti adalah Rp $645,236,300$ digunakan untuk biaya bunga tabungan, biaya bunga simpanan berjangka, biaya lain-lain, biaya pegawai, biaya kantor, biaya perjalanan, biaya penyusutan, biaya pinjaman ragu-ragu, biaya organisasi, biaya jasa pengawas dan pengurus dan biaya lain-lain, sedangkan tahun 2016 biaya operasional KSP Artha Guna Bhakti adalah $\mathrm{Rp} 738,187,240$, bertambahnya akumulasi penyusutan KSP Artha Guna Bhakti yaitu sebesar Rp 3,500,000, karena pada tahun 2015 akumulasi penyusutan KSP Artha Guna Bhakti adalah Rp 37,800,000, sedangkan tahun 2016 akumulasi penyusutan KSP Artha Guna Bhakti adalah Rp 41,300,000 Hasil analisis penggunaan modal kerja yang telah dilakukan pada KSP Artha Guna Bhakti pada periode tahun 2016-
2017, total penggunaan modal kerja pada periode tahun 2016-2017 adalah $\mathrm{Rp}$ $1,286,634,460$, dapat diuraikan unsur-unsur non current yang memperkecil modal kerja (penggunan modal kerja). Penggunaan modal kerja pada KSP Artha Guna Bhakti periode tahun 2016-2017 yaitu berkurangnya piutang harian KSP Artha Guna Bhakti yaitu sebesar Rp 28,780,400, karena pada tahun 2016 piutang harian KSP Artha Guna Bhakti adalah Rp 399,338,000, sedangkan tahun 2017 piutang harian KSP Artha Guna Bhakti adalah $\mathrm{Rp} 370,557,600$, bertambahnya piutang bulanan KSP Artha Guna Bhakti yaitu sebesar $R p 1,148,861,200$, karena pada tahun 2016 piutang bulanan KSP Artha Guna Bhakti adalah Rp 2,675,476,900, sedangkan tahun 2017 piutang bulanan KSP Artha Guna Bhakti adalah $\mathrm{Rp} 3,824,338,100$, penyertaan KSP Artha Guna Bhakti yaitu sebesar $R p$ $3,700,000$, biaya operasional KSP Artha Guna Bhakti yaitu sebesar Rp 95,292,860, akumulasi penyusutan KSP Artha Guna Bhakti yaitu $R p 5,000,000$, karena pada tahun 2016 akumulasi penyusutan KSP Artha Guna Bhakti adalah Rp 41,300,000, sedangkan tahun 2017 akumulasi penyusutan KSP Artha Guna Bhakti adalah Rp 46,300,000.

Dari temuan-temuan pada penggunaan modal kerja ini sejalan dengan teori penggunaan modal kerja yang dikemukaan oleh Kasmir (2014) penggunaan modal kerja bisa dilakukan untuk pengeluaran gaji, upah, dan biaya operasional, pengeluaran untuk membeli bahan baku atau bahan dagangan, menutupi kerugian akibat penjualan surat berharga, pembentukan dana, pembelian aktiva tetap, pembayaran hutang jangka panjang, dan penggunaan lainnya.

\section{SIMPULAN DAN SARAN Simpulan}

Berdasarkan hasil analisis dan pembahasan yang telah dijelaskan sebelumnya, maka diperoleh kesimpulan sebagai berikut. Sumber modal kerja pada Koperasi Simpan Pinjam Artha Guna Bhakti periode tahun 2016-2017 berasal dari berkurangnya tabungan wajib pinjam sebesar $\operatorname{Rp} 2,705,500$, bertambahnya 
tabungan sukarela sebesar $\mathrm{Rp}$ 279,048,513, bertambahnya simpanan berjangka sebesar $\mathrm{Rp} 1,156,200,000$, berkurangnya pinjaman luar sebesar $\mathrm{Rp}$ $37,500,000$, simpanan pokok sebesar $\mathrm{Rp}$ $9,575,000$, simpanan wajib sebesar $R p$ 49,340,000, simpanan khusus sebesar $R p$ $3,000,000$, dan cadangan sebesar $\mathrm{Rp}$ $25,975,115$, penggunaan modal kerja pada Koperasi Simpan Pinjam Artha Guna Bhakti periode tahun 2016-2017 untuk pengeluaran biaya operasional sebesar $\mathrm{Rp}$ 95,292,860 yang digunakan untuk biaya pegawai, biaya perjalanan, biaya kantor, biaya bunga tabungan, biaya organisasi, biaya jasa pengawas, biaya bunga simpanan berjangka, dan biaya lain-lain, berkurangnya piutang bulanan sebesar $\mathrm{Rp}$ $28,780,400$, bertambahnya piutang bulanan sebesar $\operatorname{Rp} 1,148,861,200$, penyertaan sebesar $\operatorname{Rp} 3,700,000$, dan akumulasi penyusutan sebesar Rp 5,000,000

\section{Saran}

Berdasarkan simpulan di atas, maka dapat disarankan sebagai berikut.

Pertama bagi Koperasi Simpan Pinjam Artha Guna Bhakti.

Pertama pihak koperasi diharapkan untuk merencanakan sumber dan penggunaan modal kerja dengan baik, agar koperasi bisa berjalan dengan baik dan lancar.

Kedua Bagi Peneliti. Peneliti selanjutnya yang bermaksud melakukan penelitian di bidang koperasi, diharapkan untuk melakukan penelitian lebih lanjut dan mendalam terkait dengan analisis sumber dan penggunaan modal kerja menggunakan metode penelitian yang sama pada perusahaan lainnya atau menggunakan lebih dari satu koperasi maupun perusahaan.

\section{DAFTAR PUSTAKA}

Amidipradja, Talman dan Wirasasmita , Rivani. 2005. Neraca Koperasi. Bandung: Pionir Jaya.

Ikatan Akuntansi Indonesia. 2002. Standar Akuntansi Keuangan. Jakarta: Salemba Empat.
Jumingan. 2008. Analisis Laporan Keuangan (cetakan kedua). Jakarta: Bumi Aksara.

Kasmir. 2004. Bank dan Lembaga Keuangan Lainnya. Jakarta: PT.Raja Grafindo Persada.

-------. 2012. Analisis Laporan Keuangan. Jakarta: PT.Raja Grafindo Persada.

-------. 2014. Analisis Laporan Keuangan (cetakan ketujuh). Jakarta: PT. Raja Grafindo Persada.

Munawir, S. 2000. Analisis Laporan Keuangan Edisi Kedua. Yogyakarta: YPKN. 2002. Analisis Informasi Keuangan. Yogyakarta: PT. Liberty Jogja. - 2004. Analisis Laporan Keuangan Edisi Keempat. Yogyakarta: Liberty.

Riyanto, Bambang. 2001. Dasar-dasar Pembelajaran. Yogyakarta: BPFE.

Rudianto, 2010. Akuntansi Koperasi Edisi Kedua. Jakarta: Erlangga.

Sartono, Agus. 2010. Manajemen Keuangan Teori dan Aplikasi Edisi Keempat Cetakan Keempat. Yogyakarta: BPFE.

Sitio, Arifin. 2001. Koperasi Teori dan Praktik. Jakarta: Erlangga.

Subandi. 2010. Ekonomi Koperasi Teori dan Praktek. Bandung: Alfabeta.

Sudarsono, \& Edilius. 2004. Manajemen Koperasi Indonesia. Jakarta: Rineka Cipta.

Sujarweni, Wiratna. 2017. Analisis Laporan Keuangan. Yogyakarta: Pustaka Baru Press.

Sukamdiyo, Ign. 2010. Manajemen Koperasi. Jakarta: Erlangga.

Sutrisno. 2007. Manajemen Keuangan Teori, Konsep, dan Aplikasi. Yogyakarta: Ekonisia. 